\title{
VARIATION IN LOBES AND FISSURES OF LUNG
}

\section{Jaideo M Ughade *1, Poorwa B Kardile 2, Pawan R Tekade ${ }^{3}$.}

${ }^{* 1}$ Associate Professor, Department of Anatomy, Late Lakhiram Agrawal Memorial Government Medical College, Raigarh, Chhattisgarh, India.

${ }^{2}$ Assistant Professor, Department of Anatomy, Dr Shankarrao Chavan Government Medical College, Nanded, Maharashtra, India.

${ }^{3}$ Professor, Department of Forensic Medicine and Toxicology, Late Lakhiram Agrawal Memorial Government Medical College, Raigarh, Chhattisgarh, India.

\section{ABSTRACT}

Introduction: Lungs are the paired vital organs meant for respiration situated in the thoracic cavity on either side of the heart. The right lung is divided into supe-rior, middle \& inferior lobes by oblique and horizontal fissure. While the left lung is divided into supe-rior \& inferior lobes by an oblique fissure. The fissures permit distension of the lobes during respiration. The fissures may be complete, incomplete or absent.

Aim: To find out the variations in fissures and lobes along with their patterns, in human lungs; collected from cadavers.

Result: Out of 50 right lung specimen, the horizontal fissure was absent in two cases whereas the horizontal fissure was incompletely seen in 18 specimens. Incomplete oblique fissure was seen in 7 right sided lungs. We reported accessory fissures and accessory lobes in 14 specimens. The oblique fissure was absent in 4 left lungs and it was incomplete in 14 lungs. Accessory fissures and lobes were present in 8 specimens.

Conclusion: Knowledge of any variations is necessary in performing segmental resection and lobectomy. Accessory fissures indicate persistence of prenatal fissures.

KEY WORDS: Fissures of Lung, Accessory Fissures, Accessory Lobes.

Address for Correspondence: Dr. Jaideo Ughade, Associate professor, department of Anatomy, Late Lakhiram Agrawal Memorial Government Medical College, Bendrachua, Raigarh 496001

E-Mail: drjaideoughade@gmail.com

Access this Article online

Quick Response code

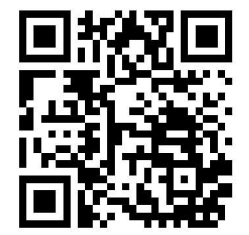

DOI: $10.16965 /$ ijar.2018.101
Journal Information

International Journal of Anatomy and Research

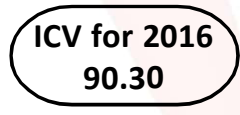

ISSN (E) 2321-4287 | ISSN (P) 2321-8967

https://www.ijmhr.org/ijar.htm

DOI-Prefix: https://dx.doi.org/10.16965/ijar

\section{Article Information}

Received: 01 Jan 2018

Peer Review: 01 Jan 2018

Revised: None
Accepted: 02 Feb 2018

Published (O): 05 Mar 2018

Published (P): 05 Mar 2018

\section{INTRODUCTION}

Lungs are the paired vital organs meant for respiration situated in the thoracic cavity on either side of the heart. The right lung is divided into supe-rior, middle \& inferior lobes by oblique and horizontal fissure. The left lung is divided into supe-rior \& inferior lobes by an oblique fissure. The oblique fissure cuts the vertebral border of both lungs at the level of 4th or 5th thoracic spine. The oblique fissure runs down ward on the costal surface, continue across the diaphragmatic surface $\&$ ends below the hilum on to the medial sur-face. Horizon-tal fissure is present only in the right lung. It starts from oblique fissure, runs laterally \& transversely over the costal surface then to the anterior margin \&finally back to the hilum [1].

The fissures permit distension of the lobes during respiration [2]. The fissures may be complete, incomplete or absent. 
When the lobes of the lung are attached with each other only at the hilum by the pulmonary blood vessels and bronchi, the fissures are said to be complete. When the fissures are partly fused by parenchymal tissue between the lobes they are incomplete. Fissures assist in locating the bronchopulmonary segments [3]. Knowledge of such variations is necessary in performing segmental resection and lobectomy. Accessory fissures indicate persistence of prenatal fissures. An incomplete fissure may cause post operative air leakage [4]. Present study was conducted to note the variations in fissures and lobes of the lung in human cadavers and compare the findings with previous studies.

Aim and objectives: To find out the variations in fissures and lobes along with their patterns, in human lungs; collected from cadavers.

\section{MATERIALS AND METHODS}

A descriptive study to assess the variations in presence and completeness of fissures and lobes of the lung in human cadavers was conducted in the Department of Anatomy of Government medical colleges of Raigarh, Nanded and Yavatmal over a period of four years. Formalin fixed cadaveric lungs were collected while doing undergraduate dissection classes. Total number of speci-mens examined was 100 (50 of right side and 50 of left side). Variations in the form of complete, incomplete, absent, accessory fissure and lobe, if any were noted. The lobes and fissures of the lungs were observed for presence of variations in morphological features (i.e. complete, incomplete or presence, absence) and presence of any variant fissure, accessory fissure was noted and specimens were photographed.

\section{RESULTS}

Among the total 100 specimens, 50 were of right side and 50 were of left side. The laterality was judged based on the hilar structures.

Right lung: Out of 50 right lung specimen, the horizontal fissure was completely absent in two cases whereas the horizontal fissure was incompletely seen in 18 specimens. Complete absence of oblique fissure was not seen in any case out of 50 right lung specimens. Incomplete oblique fissure was seen in 7 right lungs. We reported
Accessory fissures and accessory lobes in 14 specimens.

Left lung: The oblique fissure was absent in 4 left lungs and it was incomplete in 14 lungs. Accessory fissures and lobes were present in 8 specimens.

Fig. 1: Absence of fissure in left lung.

Fig. 2: Accessory fissure in right lung.

Fig. 3: Accessory lobe on costal surface of lung.
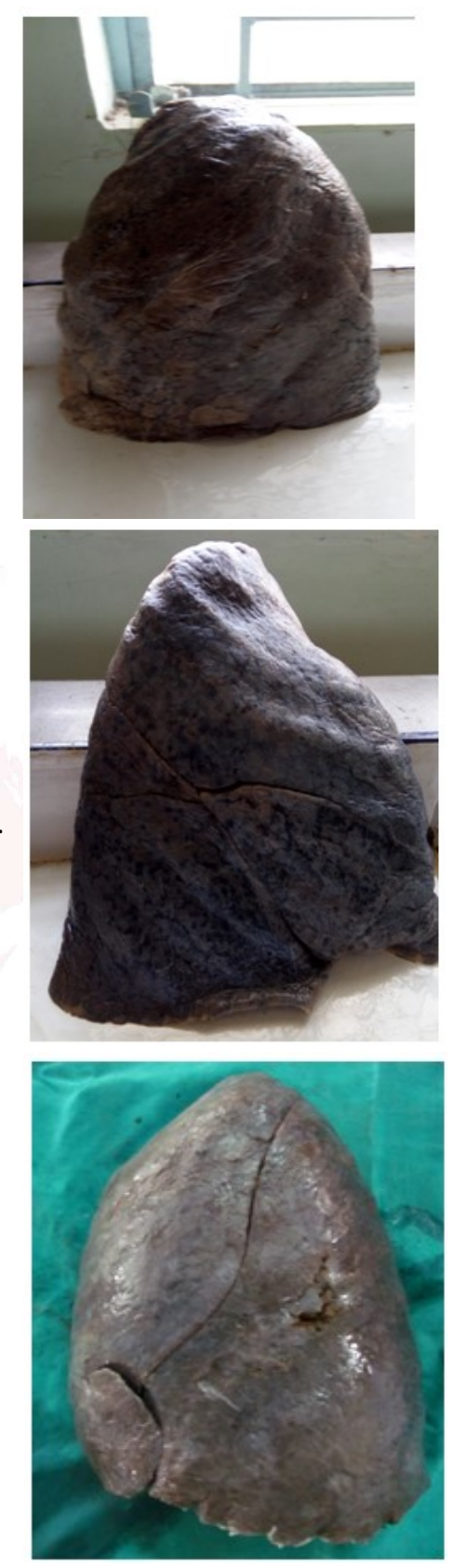

Fig. 4: Accessory fissure and lobe on diaphragmatic surface of lung.

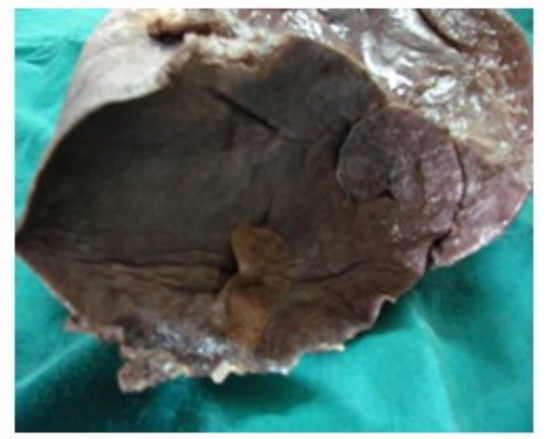


Fig. 5: Accessory fissure and lobe on mediastinal surface of lung.

Fig. 6: Incomplete horizontal fissure.

Fig. 7: Incomplete fissure not cutting the parenchyma of lung.
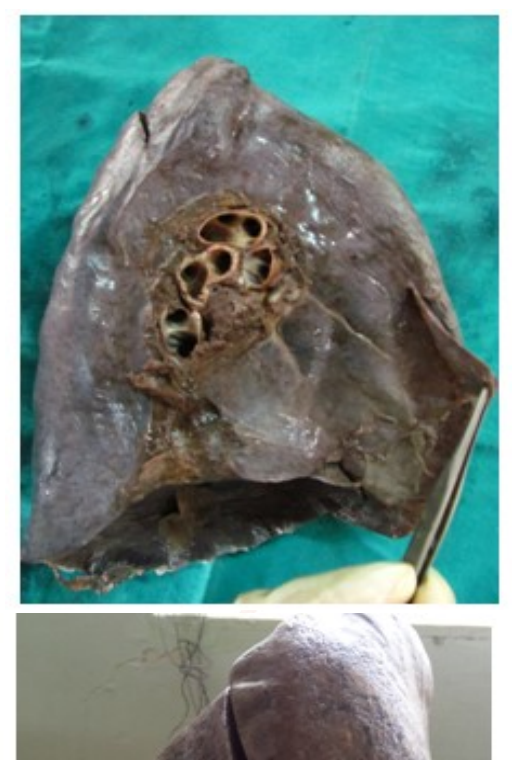

The percentage of variations was higher in the study conducted by Dutta et al.

The presence of accessory fissure was noted in $38 \%$ specimen of right side and $32 \%$ specimen of left side by Ambali MP et al [8], Azmera Gebregziabher et al [9] showed presence of accessory fissure and accessory lobe in 2 lungs (8.69\%) out of 23 right lungs. Accessory fissure was noted in $3(15 \%)$ left lung specimens. We reported Accessory fissures and accessory lobes in 14 right sided specimens and accessory fissures and lobes were present in 8 left sided specimens.

The mucosal linings of the bronchi and the epithelial cells of the alveoli are endodermal in origin. The vasculature, muscles \& cartilage of the bronchi are derived from mesoderm. Lung bud appears as an outgrowth from the ventral wall of the foregut which bifurcates into right and left primary bronchial buds. The right bronchial bud branches into three secondary bronchial buds while the left one branches into two. At about 6 th week of intrauterine life, the secondary bronchial buds branch into tertiary bronchial buds to form bronchopulmonary segments. The spaces between bronchopulmonary segments get obliterated except along the line of division of principal bronchi where deep complete fissures remain dividing the right lung into 3 lobes and left lung into 2 lobes. These fissures are oblique and horizontal in position in right lung where as only in oblique position in left lung [10]. Incomplete or absence of oblique and horizontal fissures could be due to defective obliteration of these fissures either completely or incompletely whereas accessory fissures may be present due to non obliteration Table 1: Showing the Percentage of lobes in the present study.

\begin{tabular}{|c|c|c|c|}
\hline Side & Fissure & Type & $\begin{array}{c}\text { Present } \\
\text { study }\end{array}$ \\
\hline \multirow{4}{*}{ Right lung } & \multirow{2}{*}{$\begin{array}{c}\text { Oblique } \\
\text { fissure }\end{array}$} & Incomplete & $14 \%$ \\
\cline { 3 - 4 } & $\begin{array}{c}\text { Horizontal } \\
\text { fissure }\end{array}$ & Absent & $0 \%$ \\
\cline { 3 - 4 } Left lung & \multirow{2}{*}{$\begin{array}{c}\text { Oblique } \\
\text { fissure }\end{array}$} & Absemplete & $36 \%$ \\
\cline { 3 - 4 } & & Incomplete & $4 \%$ \\
\hline
\end{tabular}

\section{DISCUSSION}

The percentage of variations in lobes and fissures in present study were similar to the study conducted by Varalakshmi et al.

of spaces which should normally get obliterated [11].

Table 2: Showing the present study findings while comparing with previous studies.

\begin{tabular}{|c|c|c|c|c|c|c|}
\hline \multirow{2}{*}{ Side } & Fissure & Type & $\begin{array}{c}\text { Varalakshmi } \\
\text { et al. [5] }\end{array}$ & $\begin{array}{c}\text { Dutta } \\
\text { et al. [6] }\end{array}$ & $\begin{array}{c}\text { Devi } \\
\text { et al [7] }\end{array}$ & $\begin{array}{c}\text { Present } \\
\text { study }\end{array}$ \\
\hline \multirow{4}{*}{ Right lung } & $\begin{array}{c}\text { Oblique } \\
\text { fissure }\end{array}$ & Incomplete & $16.70 \%$ & $61.54 \%$ & $9 \%$ & $14 \%$ \\
\cline { 2 - 8 } & Absent & $0 \%$ & $11.40 \%$ & $0 \%$ & $0 \%$ \\
\hline & $\begin{array}{c}\text { Horizontal } \\
\text { fissure }\end{array}$ & Incomplete & $30 \%$ & $38.89 \%$ & $18 \%$ & $36 \%$ \\
\cline { 3 - 8 } Left lung & $\begin{array}{c}\text { Oblique } \\
\text { fissure }\end{array}$ & Incomplete & $29.40 \%$ & $48 \%$ & $36 \%$ & $28 \%$ \\
\cline { 3 - 8 } & Absent & $3 \%$ & $8 \%$ & $9 \%$ & $8 \%$ \\
\hline
\end{tabular}




\section{CONCLUSION}

In the present study percentage of incomplete horizontal fissure of right side was higher followed by incomplete oblique fissure of left side. There is wide range in variation of horizontal, oblique and accessory fissures in present study compared to previous studies. This may be contributed by genetic and environmental factors.

Knowledge of such variations will be helpful to the radiologist, clinician to make correct diagnosis and plan for the surgical procedure. This will help to reduce the morbidity and mortality associated with lung surgeries [12].

\section{Conflicts of Interests: None}

\section{REFERENCES}

[1]. Standring S. Gray's Anatomy. 39th ed. Churchill Livingstone, New York 2005: 945-949.

[2]. Tarver RD. How common are incomplete pulmonary fissures, and what is their clinical significance? AJR Am J Roentgenol 1995;164(3):761.

[3]. Meenakshi S, Manjunath KY, Balasubramanyam V. Morphological variations of the lung fissures and lobes. Indian J Chest Dis Allied Sci 2004;46(3):179182.

[4]. Arora K, Verma P, Kullar S, Sharma K, Singla R and Mahajan A.Variations of fissures of lungs. Rev Arg de Aant clin; 2012;4(2):50-56.

[5]. Varalakshmi KL, Nayak NJ, Sangeetha M. Morphological variations of fissures of lung; an anatomical study. Indian Journal of applied research; 2014;4(8):467-469.
[6]. Dutta S, Mandal L, Mandal K, Biswis J, Ray A, Bandopadhay M. Natural fissures of lung -Anatomical basis of surgical techniques and imaging. National Journal of Medical Research, 2013;3(2):117121.

[7]. Devi B, Rao N, Sunitha V. Morphological variations of lung. A cadaveric study in north coastal Andhra Pradesh. Int J Bio Med Res; 2011;2(4):1149-1152.

[8]. Ambali MP, Jadhav SD, Doshi M, Patil R, Roy P, Desai RR. Variations of Lung Fissures: A Cadaveric Study. Journal of Krishna Institute of Medical Sciences University. 2014;3(1):85-89.

[9]. Gebregziabher A, Berhe T, Ekanem P. Variations of Fissures and Lobes of the Lungs in Human Cadavers in Selected Universities of Ethiopia. International Journal of Pharma Sciences and Research. 2015;6(6):981-990.

[10]. Sadler TW. Langman's Medical Embryology. $9^{\text {th }}$ ed. Lippincott Williams \& Wilkins. Baltimore, Maryland. 2004;223-284.

[11]. Modgil V, Das S, Suri R. Anomalous lobar pattern of right lung: A case report. Int. J. Morphol, 2006;24:56.

[12]. Glazer H, Anderson D, Dicroce J. Anatomy of the major fissure; evaluation with standard and thin section CT. Radiology. 1991;180:839-844.

How to cite this article:

Jaideo M Ughade, Poorwa B Kardile, Pawan R Tekade. VARIATION

IN LOBES AND FISSURES OF LUNG. Int J Anat Res 2018;6(1.3):5020-5023. DOI: 10.16965/ijar.2018.101 